\title{
Magatartás-változtatás az egészségügyben: a motivációs interjú
}

\author{
Pócs Dávid dr. - Hamvai Csaba dr. - Kelemen Oguz dr.
}

Szegedi Tudományegyetem, Általános Orvostudományi Kar, Magatartástudományi Intézet, Szeged

Ismert népegészségügyi tény, hogy Magyarországon a korai halálozás megelőzhető lenne dohányzásleszokással, alkoholabsztinenciával, rendszeres mozgással, egészséges táplálkozással és az adherencia növelésével. Az orvos-beteg találkozások többségén ezek a területek előtérbe kerülnek. A szakirodalom azt is alátámasztotta, hogy az egészség-magatartás megváltoztatásában az egyén számára nem a külső információ dominál, hanem a saját, belső motivációja. Ebből a felismerésből született az úgynevezett „motivációs interjú”, ami egy személyközpontú szemléleten alapuló, célorientált tanácsadási módszer. Az interjú során az orvos irányított kérdésekkel feltárja a kliens motivációit, erősségeit, erőforrásait, és ezeket állítja a beszélgetés fókuszába. Minél mélyebben és minél többet beszél az interjúalany a viselkedésváltozásról, annál nagyobb a változás esélye. Ugyanakkor az interjú folyamán a kliens szóba hozhatja ellentmondásos érzelmeit és gondolatait is a változással kapcsolatban. Orvosként ezt az ambivalenciát különböző kommunikációs stratégiák segítségével érdemes megvilágítani és feloldani. Továbbá a megfelelő orvos-beteg kapcsolat kialakítása is nélkülözhetetlen eleme a motivációs interjúnak. Ha ez a kapcsolat optimális, akkor a kliens nyíltan fog beszélni saját motivációiról és ellenállása csökken, ami szintén jobb kimenetelhez vezet. Az egészség-magatartás megváltoztatásában a motivációs interjú a „Hogyan?” kérdése helyett inkább a „Miért?”-re fókuszál, és azon belül is nem a meggyőzésre, hanem a kliens saját, belső motivációira épít. Valószínúleg ezért vált nemzetközileg is elismert és evidenciákon alapuló módszerré.

Orv Hetil. 2017; 158(34): 1331-1337.

Kulcsszavak: motivációs interjú, motiváció, magatartás, viselkedésváltoztatás, egészség

\section{Health behavior change: motivational interviewing}

Public health data show that early mortality in Hungary could be prevented by smoking cessation, reduced alcohol consumption, regular exercise, healthy diet and increased adherence. Doctor-patient encounters often highlight these aspects of health behavior. There is evidence that health behavior change is driven by internal motivation rather than external influence. This finding has led to the concept of motivational interview, which is a person-centered, goal-oriented approach to counselling. The doctor asks targeted questions to elicit the patient's motivations, strengths, internal resources, and to focus the interview around these. The quality and quantity of the patient's change talk is related to better outcomes. In addition, the interview allows the patient to express ambivalent feelings and doubts about the change. The doctor should use various communication strategies to resolve this ambivalence. Furthermore, establishing a good doctor-patient relationship is the cornerstone of the motivational interview. An optimal relationship can evoke change talk and reduce the patient's resistance, which can also result in a better outcome. The goal of the motivational interview is to focus on the 'why' to change health behavior rather than the 'how', and to utilize internal motivation instead of persuasion. This is the reason why motivational interview has become a widely-accepted evidence based approach.

Keywords: motivational interview, motivation, behavior, behavior change, health

Pócs D, Hamvai Cs, Kelemen O. [Health behavior change: motivational interviewing]. Orv Hetil. 2017; 158(34): $1331-1337$.

(Beérkezett: 2017. június 13.; elfogadva: 2017. július 10.) 


\section{Rövidítések}

CAT $=($ Commitment - Activation - Taking steps $)$ elkötelezettség - lendület - lépések; DARN $=($ Desire - Ability - Reasons - Need) vágy - képességek - okok - szükség; DEARS = (Develop discrepancy - Express empathy - Avoid argumentation - Roll with resistance - support self-efficacy) Ellentmondások feltárása - Empátia kifejezése - Vitatkozás elkerülése Ellenállás elkerülése - Önhatékonyság támogatása; MI = (motivational interviewing) motivációs interjú; MITI $=($ Motivational Interviewing Treatment Integrity) Motivációs Interjú Terápiás Integritás Kódrendszer; OARS $=($ Open question Affirmation - Reflective listening - Summary) nyitott kérdés - megerősítés - reflektív hallgatás - összegzés; READS = (Roll with resistance - Express empathy - Avoid argumentation Develop discrepancy - Support self-efficacy) Ellenállás elkerülése - Empátia kifejezése - Vitatkozás elkerülése - Ellentmondások feltárása - Önhatékonyság támogatása; RULE $=($ Resist the righting reflex - Understanding your client's motivation Listen to your client - Empower your client) Ne akarja megváltoztatni - Próbálja megérteni a kliens motivációját - Hallgassa meg a klienst - Hatalmazza fel a klienst a változásra

A motivációs interjú személyközpontú szemléleten alapuló, célorientált tanácsadási módszer, amelynek célja, hogy segítse az embereket a viselkedésváltozásban [1]. Ezt a módszert William R. Miller és Stephen Rollnick klinikai pszichológusok dolgozták ki és alkalmazták először körülbelül 20-30 éve, kezdetben alkoholdependens betegeknél [2]. Napjainkra az addiktológiában elismert és evidenciákkal támogatott módszer a DSM-5 által kategorizált szerhasználati zavarok (substance use disorder) esetében [3]. Az elmúlt 10-20 évben kutatások középpontjába került, hogy vajon a motivációs interjú alkalmazható-e más egészség-magatartásoknál is. Bár számos tanulmány igazolta a módszer hatékonyságát az elhízásban és más krónikus betegségek gondozásában is, további kutatások szükségesek az irányelvek kidolgozásához. Elhízás kapcsán a fizikai aktivitás fokozásában [4] és az egészséges táplálkozás kialakításában [5] egyaránt szignifikáns javulást igazoltak. Különböző krónikus betegségek kapcsán az adherencia növelésében és az életminőség javításában bizonyult hatékonynak: például szívelégtelenségben [6], sclerosis multiplexben [7], krónikus veseelégtelenségben [8], szkizofréniában [9] vagy krónikus obstruktív tüdőbetegségben [10]. Ezenkívül a módszer egyes elemei olyan területeken is jól alkalmazhatók, ahol nem a viselkedésváltozás a cél, például a palliatív kommunikációban [11]. Széles körú indikációs területe mellett a motivációs interjúnak gyakorlatilag nincs abszolút kontraindikációja. Természetszerúen különböző kognitív deficiteknél az interjú korlátozottan alkalmazható.

A motivációs interjú a pszichológiai és pszichiátriai gyakorlatban használt különböző tanácsadási módszereket gyújtött egybe. Nem igényel pszichoterápiás végzettséget, mert ez nem pszichoterápia. Egy összefoglaló tanulmány szerint a módszer hatékonyságát nem befolyásolta a felsőoktatási végzettség, azaz megfelelő felkészítést követően orvosok, fogorvosok, pszichológusok, egészségügyi szakdolgozók, továbbá pedagógusok is sikerrel alkalmazták [12]. Az interjú jellemzően egynégy alkalommal már hatékony, és természetesen annál effektívebb, minél többször alkalmazzák. Általában egy alkalom 15-45 percig tart, és léteznek úgynevezett „,rövidített" motivációs interjúk is. A szakirodalom minimum 20 perces időtartamot javasol [12].

\section{Meggyőzés vagy motivációs interjú?}

Az összehasonlíthatóság érdekében az 1. táblázatban összefoglaltuk, hogy mik a legfontosabb különbségek a meggyőzésen alapuló tanácsadás és a motivációs interjú között. A tanácsadási módszerek e két véglete elsősorban abban tér el, hogy mennyire ad teret a kliensnek. A motivációs interjú arra irányul, hogy a kliens mondja ki, hogy számára mi a motiváló tényező, míg a meggyőzésen alapuló tanácsadásban a kliens passzív, fókuszában az orvos érvelése áll [13]. A kliens bevonásának másik elönye, hogy az autonóm módon motivált viselkedésváltozás tartósabb, mint a kikényszerített változás [14]. Ugyanakkor nem célszerú teljes mértékben átadni az irányítást a kliensnek. A motivációs interjú kommunikációs stílusa az együttmúköodés kialakításán alapul (vezetô stílus), szemben azzal, ha kizárólag az orvos irányítja a beszélgetést (irányító stílus) vagy ha csak a kliens irányít (követő stílus). A meggyőzésen alapuló tanácsadás során alkalmazott irányító stílus ellenállást szül és hátráltatja a klienst a viselkedésváltozásban [15].

A szakirodalom a motivációs interjú „Szellemiségének” nevezi („Spirit of Motivational Interviewing”) a következő jellemzőket: a kliens motivációinak felidézését („evocation”), a partneri viszony kialakítását („partnership”), a kliens igényeinek előtérbe helyezését („,compas-

1. táblázat | Végletek a tanácsadási szemléletekben: a meggyőzésen alapuló tanácsadás és a motivációs interjú

\begin{tabular}{|c|c|c|}
\hline & Meggyőzésen alapuló tanácsadás & Motivációs interjú \\
\hline Fókusz & Meggyőzés, rábeszélés & $\begin{array}{l}\text { Saját motivációk } \\
\text { feltárása }\end{array}$ \\
\hline Páciens & Passzív szerep & Aktív szerep \\
\hline Stílus & Irányító stílus & Vezető stílus \\
\hline Módszer & $\begin{array}{l}\text { Egészségügyi oktatás és érvelés } \\
\text { a változás mellett }\end{array}$ & $\begin{array}{l}\text { Kérdezés } \\
\text { és a páciens érveinek, } \\
\text { motivációinak } \\
\text { felidézése }\end{array}$ \\
\hline Taktika & $\begin{array}{l}\text { Rábeszélés a konfrontálódás } \\
\text { és vitatkozás árán is }\end{array}$ & $\begin{array}{l}\text { Partneri viszony } \\
\text { és együttmúködés } \\
\text { kialakítása }\end{array}$ \\
\hline Figyelem & $\begin{array}{l}\text { Nincs tekintettel a páciens } \\
\text { igényeire }\end{array}$ & $\begin{array}{l}\text { Figyelembe veszi } \\
\text { a páciens igényeit }\end{array}$ \\
\hline Elfogadás & $\begin{array}{l}\text { Nem fogadja el a páciens } \\
\text { autonómiáját, értékeit, érzéseit }\end{array}$ & $\begin{array}{l}\text { Autonómia, értékek } \\
\text { és érzések elfogadása }\end{array}$ \\
\hline Felépítés & Általában nem strukturált & $\begin{array}{l}\text { Strukturált, } \\
\text { célorientált }\end{array}$ \\
\hline
\end{tabular}


sion”), illetve autonómiájának, értékeinek, érzéseinek elfogadását („acceptance”) [1]. A meggyőzésen alapuló tanácsadásra ezek ellenkezője jellemző, pedig ezek a sajátságok természetszerúen erősítik az orvos-beteg kapcsolatot. A mindennapi orvosi gyakorlatban a két tanácsadási módszert általában keverten használjuk. A motivációs interjú azonban lehetőséget nyújt arra, hogy tudatosan és strukturáltan alkalmazzunk olyan módszereket, amelyekkel a viselkedésváltozás esélye növelhető.

\section{Alapelvek és készségek}

A motivációs interjú komponenseit az 1 . ábra foglalja össze. A módszer szerzői a korábban ismertetett „szellemiségnek” megfelelően összeállítottak bizonyos alapelveket, amelyekkel egyfajta szemléleti keretet kívántak biztosítani [1]. Erre a szemléletrendszerre épülnek bizonyos alapkészségek, amelyek fejlesztése nélkülözhetetlen a kommunikációs stratégiák elsajátításához.

A 2002-ben közölt öt alapelvet a szakirodalom „READS” vagy „DEARS” mozaikszavakkal említi. Az „Ellenállás elkerülése” („Roll with resistance”) alapelv arra utal, hogy a kliens kompetenciaérzése csökkenti az ellenállását, ezért érdemes rámutatni a kliens autonómiájára, és hogy a beszélgetés róla szól [16]. Az „Empátia kifejezése” („Express empathy”) alapelv szerint a kliens érzéseinek, tapasztalatainak és szemszögének megértése és ennek kifejezése segíti a változást. A „Vitatkozás elkerülése” („Avoid argumentation”) alapelv szerint ajánlott úgy vezetni a beszélgetést, hogy a kliens érveljen a viselkedésváltozás mellett, ne az orvos. Ez az első három alapelv erősíti az orvos-beteg kapcsolatot [17]. Az „Ellentmondások feltárása” („Develop discrepancy”) alapelv szerint a változást segíti a kliens személyes céljai, értékei, illetve a jelenlegi káros viselkedés közötti ellentmondások felismerése. Végül az „Önhatékonyság támogatása” („Support self-efficacy”) alapelv szerint a kliens és az orvos meggyőződése arról, hogy a kliens képes a változásra, nagymértékben elősegíti a viselkedésváltozást. Fontos továbbá kiemelni, hogy az önbecsülés hasznos, de nem nélkülözhetetlen a viselkedésváltozáshoz, szemben az önhatékonysággal, amely specifikus, egy adott célra vonatkozik és magába foglalja a tervezés és a kivitelezés lépéseit is, ami már a „Hogyan?” kérdésköréhez tartozik [18].

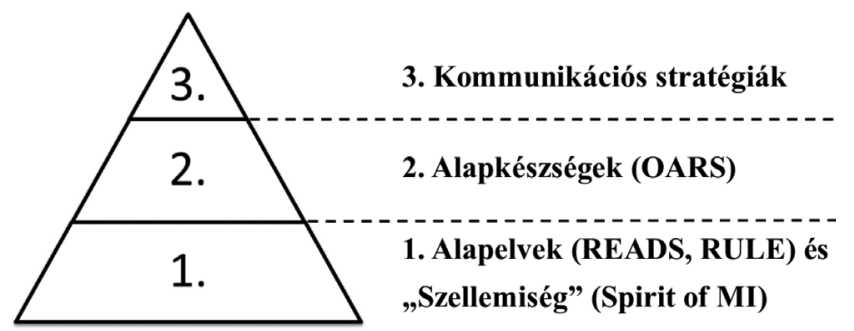

1. ábra | A „motivációs interjú” tanácsadási szemlélet komponensei
A módszer fejlődését jól szemlélteti, hogy 2008-ban a szerzők az alapelveket hasonló tartalommal, de más szempontok szerint csoportosították. Ezek az úgynevezett „RULE-alapelvek” a tanácsadási attitüdben kívánnak irányt mutatni. A „Ne akarja megváltoztatni!” ( „Resist the righting reflex!") alapelv arra utal, hogy az orvosban van egy segítő szándék, amely sokszor erőteljesen és reflexszerüen arra késztet, hogy megváltoztassa a klienst. Tanácsos tudatosan leküzdeni ezt a jobbító, javító „reflexet”, mert ez rontja az orvos-beteg kapcsolatot. Ugyanakkor megjegyeznénk, hogy ez az egyik legnehezebb pont, hiszen orvosként felelősséget érzünk a kliens gyógyulása iránt, ezért nagyon erős a jobbítás célja által vezérelt, irányító késztetés. Meg kell tanulnunk, hogy a megosztott döntési helyzetben a felelősség is megosztott. El kell tudnunk engedni a megváltoztatási törekvésünket éppen azért, hogy a változást a kliens maga tudja kidolgozni. A második alapelv lényege a „Próbálja megérteni a kliens motivációját!” („Understanding your client's motivation!”), azaz, hogy a motiváció a klienstől jön, az orvos érdeklődése és a kliens bevonása javítja az együttmúködést, illetve a motiváció megértése segíti a tervezést és a kivitelezést. A „Hallgassa meg a klienst!” ( „Listen to your client!”) alapelv szerint a hallgatás a motivációs interjúban egy aktív folyamat, ugyanakkor időt is ad az orvosnak a strukturált, célorientált kommunikációra. A „Hatalmazza fel a klienst a változásra!” („Empower your client!”) alapelv arra hívja fel a figyelmet, hogy minden változás önváltozás, és az orvos sosem kérdőjelezheti meg, hogy a kliens képes-e a változásra [19].

A motivációs interjú négy készség fejlesztését különösen fontosnak tartja, ezek az úgynevezett „OARS” alapkészségek: nyitott kérdés („Open question”), megerősítés („Affirmation”), reflektív hallgatás („Reflective listening”) és összegzés („Summary”) [1]. Az eldöntendő, zárt kérdések alkalmasak a gyors és precíz anamnézisfelvételre, de nem célravezetők a motivációs interjúban. A nyitott kérdések használata ugyanakkor nagyobb odafigyelést igényel, de segítségükkel a kliens könnyebben kifejtheti saját motivációját. A megerősítés kihangsúlyozza a kliens pozitív erőfeszítéseit, tulajdonságait vagy viselkedését. Fontos, hogy egy valós és konkrét pozitívumra irányuljon, azaz nem nevezhető megerősítésnek az általános dicséret, a helyeslés vagy az egyetértés. A reflexió a kliens mondandójának (fooleg a jelentéstartalmának) a visszatükrözése. A motivációs interjúban egyszerú reflexiónak nevezik a jelentéstartalom megismétlését. Ezzel szemben az összetett reflexió egy további jelentéstartalommal bír, amely arra irányul, amire a kliens gondolhatott. Például a kliens ezt mondja: „Mások is dohányoznak, még sincs semmi bajuk.” Erre az orvos így válaszol: „Ez elgondolkodtató. Ezzel azt mondja, hogy azok a dohányosok egészségesek." A minta is mutatja, hogy a reflexió célja a visszatükrözés, ezért ez nem kérdő, hanem egy kijelentő mondat. Ugyanakkor közvetíti a kliens megértését is, így erősíti az orvos-beteg kapcsolatot. 
Az orvos célja, hogy segítse a klienst a viselkedésváltozásban, ezért arra kell vigyázni, hogy nem lehet szarkasztikus vagy gúnyos a visszatükrözés. Végül az összegzés a motivációs interjú negyedik alapkészsége. Ez olyan reflexió, ami a kliens több mondatának a jelentéstartalmát tükrözi vissza. Fontos kiemelni, hogy itt az orvos az interjúból azokat a fontos elemeket hangsúlyozhatja, amelyek segítik a pácienst a viselkedésváltozásban [20].

\section{A kapcsolati kommunikációs stratégiák}

A motivációs interjúban használt kommunikációs stratégiák két csoportba sorolhatók. A kapcsolati stratégiák az orvos-beteg kapcsolat erősítésére, míg a technikai stratégiák a viselkedésváltozásra irányulnak [21]. A 2. táblázatban összefoglaltuk a motivációs interjúban használt kapcsolati stratégiákat a dohányzásleszokás támogatásában alkalmazott példamondatokkal. Az interjú nem használ új, specifikus módszert az orvos-beteg kapcsolat erôsítésére, meglévő kommunikációs módszerekből válogat, és három területre fókuszál: az együttmúködés kialakítására, az empátia kifejezésére és az ellenállás kezelésére.
Alapvetően az interjú a kliens által elmondott információkra épül [1]. Ha az orvos információt kíván átadni, az együttmúködés erősítése érdekében javasolt a hozzájárulás kérése vagy a „kérdés-kiegészítés-kérdés” („elicitprovide-elicit”) technika. Utóbbi három lépésből áll: először érdemes rákérdezni a kliens ismereteire, ezt követően azt kiegészíteni és kijavítani a tévedéseket, végül tanácsos rákérdezni, hogyan valósul meg ez a kliens életében (2. táblázat). Az egyoldalú, hozzájárulás nélküli információátadás (például az edukáció) a motivációs interjúban hibának számít, mert ellenálláshoz vezethet [19]. Tanácsos általános és semleges információkat használni (például: „A dohányzók többsége dohányzás okozta betegségben hal meg”), szemben a személyeskedő információkkal (például: „Ön a dohányzás miatt fog meghalni”). A korábban említett „OARS” készségek az együttmúködés kialakításában is hasznosak, ha a nyitott kérdések a kliens véleményére, a megerősítések a valós és konkrét pozitívumokra és a reflexiók a kliens autonómiajára és felelősségére irányulnak [20].

A kliens mondandójának van egy érzelmi jelentéstartalma is, amelynek visszatükrözése javítja az orvos-beteg kapcsolatot [17]. Az érzelmi tartalom gyakran nem a

2. táblázat |A motivációs interjú kapcsolati kommunikációs stratégiái

\begin{tabular}{|c|c|}
\hline Stratégiák & Példamondatok \\
\hline \multicolumn{2}{|l|}{ Együittmúködés kialakítása } \\
\hline Informálás beleegyezéssel & $\begin{array}{l}\text { - „A nikotinpótló készítmények sokaknak segítettek már leszokni. Megengedi, hogy ezekről beszéljek néhány } \\
\text { mondatban?” (orvos) }\end{array}$ \\
\hline „Kérdés-kiegészítés-kérdés” & $\begin{array}{l}\text { - „Kíváncsi vagyok, hogy mit tud a dohányzásleszokásról?” (orvos) } \\
\text { - „... igaza van. Szeretném kiemelni továbbá...” (orvos) } \\
\text { - „Hogyan tudja ezt elképzelni az Ön életében.” (orvos) }\end{array}$ \\
\hline Véleménykérés & $\begin{array}{l}\text { - „Vannak rossz és vannak jó módszerek a leszokásban.” (páciens) } \\
\text { - „Mire gondol? Ön hogyan látja?” (orvos) }\end{array}$ \\
\hline Megerósítés & $\begin{array}{l}\text { - „Volt, hogy már elgondolkoztam a leszokáson.” (páciens) } \\
\text { - „Örülök, hogy ilyen gondolatok foglalkoztatják.” (orvos) }\end{array}$ \\
\hline Autonómia hangsúlyozása & $\begin{array}{l}\text { - „Nem tudom, hogy mikor kezdjek neki a leszokásnak.” (páciens) } \\
\text { - „Az Ön kezében van az irányítás, ez csak magán múlik.” (orvos) }\end{array}$ \\
\hline \multicolumn{2}{|l|}{ Az empátia kifejezése } \\
\hline Egyszerű empatikus reflexió & $\begin{array}{l}\text { - „Megéreztem a cigifüstöt és úgy megkívántam.” (páciens) } \\
\text { - „Érthetô, hogy vonzza a cigarettafüst.” (orvos) }\end{array}$ \\
\hline Összetett empatikus reflexió & $\begin{array}{l}\text { - „Valamiben meg kell halni.” (páciens) } \\
\text { - „Megértem, hogy egy viccel próbálja ezt elütni.” (orvos) }\end{array}$ \\
\hline Normalizálás & $\begin{array}{l}\text { - „Megpróbáltam önerőből letenni, de nem sikerült.” (páciens) } \\
\text { - „Természetes, hogy az emberek többségének segítség kell ahhoz, hogy letegye a cigarettát.” (orvos) }\end{array}$ \\
\hline \multicolumn{2}{|l|}{ Az ellenállás kezelése } \\
\hline $\begin{array}{l}\text { Autonómia hangsúlyozása } \\
\text { Összetett empatikus reflexió } \\
\text { Fókuszváltás } \\
\text { - Véleménykérés }\end{array}$ & $\begin{array}{l}\text { - „Engem ne próbáljon meg leszoktatni!” (páciens) } \\
\text { - „Az én munkám, hogy foglalkozzak az egészségével. A leszokás viszont az Ön »asztala«, a maga kezében } \\
\text { van az irányítás. Megértem, hogy azt érzi, más bele akar ebbe szólni, és ez zavarja. Önnek fontos, hogy } \\
\text { maga döntsön a leszokásról. Emiatt kíváncsi vagyok arra, hogy az Ön számára mi az a három legfontosabb } \\
\text { ok, amiért érdemes lehet leszoknia?” (orvos) }\end{array}$ \\
\hline $\begin{array}{l}\text { Normalizálás } \\
\text { Megerósítés } \\
\text { Fókuszváltás } \\
\text { - Informálás beleegyezéssel }\end{array}$ & $\begin{array}{l}\text { - „Maga nem érti, hogy min megyek keresztül.” (páciens) } \\
\text { - „Természetes, hogy aki nincs hasonló élethelyzetben, az nehezen érti meg a másikat, és ennek a fordítottja } \\
\text { is igaz: aki ugyanabban a cipőben jár, az könnyebben megérti a másikat. Ön nagyon jól látja, hogy olyan } \\
\text { emberek, akik szintén a leszokáson gondolkoznak, segíthetnek Önnek. Ismer-e ilyen embereket? Vagy } \\
\text { ajánlhatok-e olyan közösségi portált, ahol talál ilyen embereket?” (orvos) }\end{array}$ \\
\hline
\end{tabular}


verbális, hanem a metakommunikációban jelentkezik, ezért felismerése nem mindig egyszerü. Az érzelmi jelentéstartalom felismerése és értelmezése (az empátia) kognitív szintû feldolgozást is igényel, szemben az együttérzéssel (a szimpátiával). Nem szükséges megélni ugyanazokat a tapasztalatokat, sem azonosulni vele, sem elfogadni vagy támogatni. Az orvos a megértését a reflexiók mellett a normalizáláson keresztül fejezheti ki. A normalizálás az érzelmi jelentéstartalom természetességének a megerősítése (2. táblázat). Az empatikus készség fejleszthető, segítségével korán felismerhető a kliens ellenállása.

A motivációs interjú kétfajta ellenállást különböztet meg. A viselkedésváltozásra irányuló ellenállás (ellenvetés, kifogás, „sustain talk”) csökkentésére a technikai kommunikációs stratégiák, míg az orvossal szembeni ellenállás (interperszonális konfliktus, „discord”) kezelésére a kapcsolati stratégiák használata javasolt. Orvossal szembeni ellenállásra utal, ha a kliens félbeszakítja és számon kéri az orvost, vitatkozik, mentegetőzik vagy zavartnak látszik. Ezek azt jelzik vissza az orvosnak, hogy érdemes több kapcsolati kommunikációs stratégiát használnia [17]. A motivációs interjú a konfliktuskezelés módszertanából a fókuszváltást preferálja, lehetőleg úgy, hogy a beszélgetés fókuszát az orvos a viselkedésváltozásra irányítsa (2. táblázat).

\section{A technikai kommunikációs stratégiák}

A motivációs interjú célorientált, ami azt jelenti, hogy a tanácsadási szemléletre jellemző, úgynevezett technikai stratégiák egy konkrét viselkedésváltozásra („change goal"-ra) irányulnak [1]. A célnak megfelelően a kliens mondandója felosztható a viselkedésváltozást segító mondatokra („change talk”) és a változást hátráltató mondatokra („sustain talk”).

Ezek a mondatok aszerint változnak, hogy a páciens a viselkedésváltozás melyik szakaszában áll: töprengés, elhatározás, előkészület, változtatás, fenntartás, visszaesés [22]. A motivációs interjú ennek megfelelően a változást segítő mondatokat további két csoportba sorolja. A töprengés, elhatározás és visszaesés szakaszában a páciens általában az elhatározást előkészítő mondatokat használ („preparatory change talk”), ezeket a „DARN” mozaikszóval lehet összefoglalni, mert a páciens a következőkről beszél: vágy ( „Desire”, például „akarok változni, szeretnék, kívánom”), képességek („Ability”, például „képes vagyok megváltozni, tudom, kibírom”), okok ( "Reasons”, például „van rá okom”) és szükség („Need”, „változnom kell, szükséges, muszáj, fontos”). Az előkészület, változtatás és a fenntartás szakaszában a páciens a megvalósítással kapcsolatos mondatokat használ ( „mobilizing change talk”), ezeket a „CAT” mozaikszó kapcsolja össze, mert a páciens a következőkről beszél: elkötelezettség („Commitment”, például „változni fogok, megcsinálom, akarom”), lendület ( „Activation”, például „hajlandó vagyok változni, készen állok”), lépések
(„Taking steps”, például „megcsináltam, lépéseket tettem”). Gyakorlati szempontból nem a felosztás a lényeges, hanem, hogy az orvos felismerje a viselkedésváltozást segítő mondatokat és indukálja, „müvelje” azokat ( „cultivating change talk”) [23].

A viselkedésváltozásra serkentően hat, ha a változás melletti és a változással ellentétes motivációk egy időben megjelennek a beszélgetésben, ezt a motivációs interjú ambivalenciának nevezi („ambivalence”). A változást segítő mondatok előidézésében ezért fontos szempont, hogy ellentmondásokat is generáljon az orvos. A 3. táblázatban ezeket a stratégiákat foglaltuk össze a dohányzásleszokás támogatásának példáján keresztül. Az előreés visszatekintés stratégiája egy időbeli ambivalenciára törekszik a jelenlegi káros viselkedés és a múlt vagy jövőbeli egészséges viselkedés között. A kliens céljai és értékrendje is szembeállítható a jelenlegi káros viselkedéssel, illetve annak szélsőséges pozitív és negatív kimenetelei is ütköztethetők. A „döntési egyensúly” stratégiája egy meghatározott sorrend szerint mérlegre teszi a viselkedésváltozás érveit és ellenérveit [24]. Végül a „vonalzótechnika” egy-egy skálára helyezi, hogy mennyire fontos a kliens számára a változás („importance ruler”), menynyire áll készen a változásra ( „readiness ruler”) és menynyire érzi magát magabiztosnak („confidence ruler”). A „vonalzótechnika” lehetőséget nyújt arra, hogy a kliens három különböző aspektusból beszéljen a motivációiról. Praktikus továbbá, hiszen az eredmények rögzíthetők, későbbi találkozás alkalmával újra felvehetők és összehasonlíthatók. A változást segítő mondatok előidézésében továbbá jól alkalmazhatók az OARS-készségek, amenynyiben a nyitott kérdések, megerősítések és reflexiók egyenesen a változást segítő mondatokra („DARNCAT”) vagy azok részleteire, illetve azokkal kapcsolatos példákra irányulnak [23].

A páciens ellenállása a viselkedésváltozással szemben az úgynevezett változást hátráltató mondatokban jelenik meg („sustain talk”). Természetszerüen nem ajánlott ezeket a mondatokat tartósan a beszélgetés fókuszába állítani, ugyanakkor tanácsos röviden feltárni a mondatokban rejlő ambivalenciát. Ezeket a stratégiákat („softening sustain talk”) a 3. táblázatban foglaltuk össze. A felerősített reflexió célja, hogy felnagyítsa a kliens mondanivalójának mélyebb jelentéstartalmát, míg a kétoldalú reflexió célja, hogy szembeállítsa azt a változást segítő mondatokkal. A kapcsolati kommunikációs stratégiáknál korábban említett fókuszváltás és az autonómia hangsúlyozása stratégiák itt is jól alkalmazhatók, illetve kombinálhatók az empatikus reflexióval és a normalizálással. Végül egyetértést követően a pszichológiai gyakorlatban használt átkeretezés is hasznos stratégia [23].

\section{Minőségbiztosítás és kimenet}

A módszer széles körû elterjedésével szükségessé vált a minőségbiztosítás, azaz annak a mérése, hogy vajon az orvos a motivációs interjút megfelelően alkalmazza-e. 


\begin{tabular}{|c|c|}
\hline Stratégiák & Példamondatok \\
\hline \multicolumn{2}{|c|}{ Változást segítő mondatok feltárása } \\
\hline Előretekintés & $\begin{array}{l}\text { „Ön szerint mi fog történni, ha folytatja a dohányzást, és mi fog történni, ha nem folytatja? } \\
\text { Hogyan képzeli el a jövőjét?” (orvos) }\end{array}$ \\
\hline Visszatekintés & $\begin{array}{l}\text { „Mielőtt elkezdett dohányozni, más volt az élete? Például másoknak jobban ment a sport. } \\
\text { Az Ön élete miben volt más akkor?” (orvos) }\end{array}$ \\
\hline Célok, értékek & $\begin{array}{l}\text { „Milyen céljai vannak az életben? Karrier, család, anyagiak? Milyen értékek fontosak Önnek? } \\
\text { Egészség, barátok, szabadság? Ön szerint ezeket hogyan befolyásolja a dohányzás?” (orvos) }\end{array}$ \\
\hline Végletek & $\begin{array}{l}\text { „Mi lehet a dohányzás két véglete? Ön szerint mi a legjobb és mi a legrosszabb dolog, ami } \\
\text { történhet Önnel, ha dohányzik?” (orvos) }\end{array}$ \\
\hline Döntési egyensúly & $\begin{array}{l}\text { 1. „Mi a jó a dohányzásban?” (orvos) } \\
\text { 2. „Mi a rossz a dohányzásban?” (orvos) } \\
\text { 3. „Mi a rossz a leszokásban?” (orvos) } \\
\text { 4. „Mi a jó a leszokásban? (orvos) }\end{array}$ \\
\hline Vonalzótechnika & $\begin{array}{l}\text { - „Egy 0-tól 10-ig terjedő skálán Önnek jelenleg mennyire fontos, hogy leszokjon a } \\
\text { dohányzásról?” (orvos) } \\
\text { - „Három.” (páciens) } \\
\text { - „Miért a hármas értéket mondta, miért nem kettő vagy egy?” (orvos) } \\
\text { - „Mi kellene ahhoz, hogy négy vagy öt legyen?” (orvos) }\end{array}$ \\
\hline \multicolumn{2}{|c|}{ Változást hátráltató mondatok kezelése } \\
\hline Egyszerü reflexió & $\begin{array}{l}\text { - „Nem is olyan káros a dohányzás.” (páciens) } \\
\text { - „Itt beszélgetünk a szívinfarktusa után, és Ön szerint nem olyan káros a dohányzás.” (orvos) }\end{array}$ \\
\hline Felerősített reflexió & $\begin{array}{l}\text { - „Én nem vagyok függő.” (páciens) } \\
\text { - „Ezek szerint Ön bármikor le tudja tenni, akár most is.” (orvos) }\end{array}$ \\
\hline Kétoldalú reflexió & $\begin{array}{l}\text { - „Ez az egyedüli örömöm az életben.” (páciens) } \\
\text { - „Érdekes, hogy most azt mondja, ez az egyedüli örömöm, amikor korábban azt mondta, } \\
\text { örömet okozna, ha le tudna szokni.” (orvos) }\end{array}$ \\
\hline $\begin{array}{l}\text { Empatikus reflexió } \\
+ \text { Fókuszváltás }\end{array}$ & $\begin{array}{l}\text { - „Valamiben meg kell halni.” (páciens) } \\
\text { - „Megértem, hogy egy viccel próbálja ezt elütni. Viszont hogyan lehetne elkerülni azt, hogy } \\
\text { ebben kelljen meghalnia?” (orvos) }\end{array}$ \\
\hline $\begin{array}{l}\text { Normalizálás } \\
\text { + Autonómia hangsúlyozása }\end{array}$ & $\begin{array}{l}\text { - „Nekem ez a leszokás nem fog sikerülni.” (páciens) } \\
\text { - „Érthető, hogy így érez. Természetes, hogy az emberek néhányszor elbizonytalanodnak } \\
\text { a leszokás alatt. Ugyanakkor senki nem fog leszokni maga helyett, az Ön kezében van az } \\
\text { irányítás.” (orvos) }\end{array}$ \\
\hline $\begin{array}{l}\text { Egyetértés } \\
+ \text { Átkeretezés }\end{array}$ & $\begin{array}{l}\text { - „Mindenki a leszokással szekál.” (páciens) } \\
\text { - „Tudom, mire gondol. Mások akarják megmondani, mit csináljon. Ugyanakkor lehet, } \\
\text { ők csak jót akarnak Önnek.” (orvos) }\end{array}$ \\
\hline
\end{tabular}

Ennek legelterjedtebb eszköze a motivációs interjú terápiás integritását mérő MITI (Motivational Interviewing Treatment Integrity), amelyet az elmúlt évtizedekben folyamatosan fejlesztettek, jelenleg a MITI 4.2. az aktuális [25]. Lényege, hogy az interjúról hangfelvétel készül, amelyből véletlenszerüen választanak egy 20 perces időtartamot és azt értékelik ki, kezdetben globálisan, második lépésben numerikusan. (A különböző OARSkészségek, valamint a kommunikációs stratégiák használatát számolják meg.)

A szakirodalom alapján a motivációs interjúban három tényező befolyásolja szignifikánsan a viselkedésváltozás eredményességét [26]:

- a motivációs interjú szellemiségének („spirit”) és alapelveinek („principles”) sérülése negatív kimenethez vezet;
- a változást segítő mondatok („change talk”) indukálása pozitív kimenethez vezet;

- az ambivalencia („ambivalence”) feltárása pozitív kimenethez vezet.

\section{Következtetés}

A motivációs interjú személyközpontú szemléleten alapuló, célorientált, egyre szélesebb körben alkalmazott tanácsadási módszer. Hatásosságát az egészségmagatartás-változtatás területén számos tanulmány igazolja. Lehet, hogy ez a kommunikációs módszer bonyolultnak tûnik a kifejtés, leírás során, de mindig nehéz egy kommunikációs helyzetet, stílust egyszerűen megfogalmazni. Ugyanakkor bátorítanánk mindenkit, hogy próbálja ki és építse be orvosi gyakorlatába, mert egy nagyon haté- 
kony, izgalmas és az orvosi munkát is színesítő lehetőség.

Amennyiben a motivációs interjú felkeltette az érdeklődését, érdemes elolvasni más hazai összefoglalókat is [27]. Magyarországon már léteznek a motivációs interjút integráló tanfolyamok, de tudomásunk szerint önálló képzés formájában jelenleg nem elérhető. Intézetünk a jövőben tervezi ilyen akkreditált továbbképzés elindítását.

Anyagi támogatás: A közlemény megírása anyagi támogatásban nem részesült.

Szerzői munkamegosztás: P. D., K. O.: A téma felvetése. P. D., H. Cs., K. O.: A kézirat megszövegezése. A cikk végleges változatát valamennyi szerző elolvasta és jóváhagyta.

Érdekeltségek: A szerzőknek nincsenek érdekeltségeik.

\section{Irodalom}

[1] Miller WR, Rollnick S. Motivational interviewing: preparing people to change. 2nd ed. Guilford Press, New York, 2002.

[2] Miller WR. Motivational interviewing: research, practice, and puzzles. Addict Behav. 1996; 21: 835-842.

[3] Smedslund G, Berg RC, Hammerstrøm KT, et al. Motivational interviewing for substance abuse. Cochrane Database Syst Rev. 2011; 5: CD008063.

[4] Bean MK, Powell P, Quinoy A, et al. Motivational interviewing targeting diet and physical activity improves adherence to paediatric obesity treatment: results from the MI Values randomized controlled trial. Pediatr Obes. 2015; 10: 118-125.

[5] Mirkarimi K, Kabir MJ, Honarvar MR, et al. Effect of motiva tional interviewing on weight efficacy lifestyle among women with overweight and obesity: A randomized controlled trial. Iran J Med Sci. 2017; 42: 187-193.

[6] Masterson Creber R, Patey M, Lee CS, et al. Motivational interviewing to improve self-care for patients with chronic heart failure: MITI-HF randomized controlled trial. Patient Educ Couns. 2016; 99: 256-264

[7] Dashti A, Yousefi H, Maghsoudi J, et al. The effects of motivational interviewing on health promoting behaviors of patients with multiple sclerosis. Iran J Nurs Midwifery Res. 2016; 21: 640-645.

[8] García-Llana H, Remor E, del Peso G, et al. Motivational interviewing promotes adherence and improves wellbeing in pre-dialysis patients with advanced chronic kidney disease. J Clin Psychol Med Settings 2014; 21: 103-115.

[9] Fiszdon JM, Kurtz MM, Choi J, et al. Motivational interviewing to increase cognitive rehabilitation adherence in schizophrenia. Schizophr Bull. 2016; 42: 327-334.

[10] Benzo R, Vickers K, Ernst D, et al. Development and feasibility of a self-management intervention for chronic obstructive pul- monary disease delivered with motivational interviewing strategies. J Cardiopulm Rehabil Prev. 2013; 33: 113-123.

[11] Pollak KI, Childers JW, Arnold RM. Applying motivational interviewing techniques to palliative care communication. J Palliat Med. 2011; 14: 587-592.

[12] Rubak S, Sandbaek A, Lauritzen T, et al. Motivational interviewing: a systematic review and meta-analysis. Br J Gen Pract. 2005; 55: 305-312.

[13] Griffith LJ. The psychiatrist's guide to motivational interviewing. Psychiatry (Edgmont) 2008; 5: 42-47.

[14] Sohl SJ, Birdee G, Elam R. Complementary tools to empower and sustain behavior change: motivational interviewing and mindfulness. Am J Lifestyle Med. 2016; 10: 429-436.

[15] Dillard JP, Shen L. On the nature of reactance and its role in persuasive health communication. Communication Monographs 2005; 72: 144-168.

[16] Moyers TB, Rollnick S. A motivational interviewing perspective on resistance in psychotherapy. J Clin Psychol. 2002; 58: 185193.

[17] Moyers TB. The relationship in motivational interviewing. Psychotherapy (Chic.) 2014; 51: 358-363.

[18] Resnicow K, McMaster F. Motivational interviewing: moving from why to how with autonomy support. Int J Behav Nutr Phys Act. 2012; 9: 19

[19] Rollnick S, Miller WR, Butler CC. Motivational interviewing in health care: helping patients change behavior (Applications of motivational interviewing). Guilford Press, New York, 2008.

[20] Westra HA, Aviram A. Core skills in motivational interviewing. Psychotherapy (Chic.) 2013; 50: 273-278.

[21] Miller WR, Rose GS. Toward a theory of motivational interviewing. Am Psychol. 2009; 64: 527-537.

[22] Prochaska JO, Velicer WF. The transtheoretical model of health behavior change. Am J Health Promot. 1997; 12: 38-48.

[23] Apodaca TR, Jackson KM, Borsari B, et al. Which individual therapist behaviors elicit client change talk and sustain talk in motivational interviewing? J Subst Abuse Treat. 2016; 61: 6065 .

[24] Miller WR, Rose GS. Motivational interviewing and decisional balance: contrasting responses to client ambivalence. Behav Cogn Psychother. 2015; 43: 129-141

[25] Moyers TB, Rowell LN, Manuel JK, et al. The Motivational Interviewing Treatment Integrity Code (MITI 4): Rationale, preliminary reliability and validity. J Subst Abuse Treat. 2016; 65: $36-42$.

[26] Apodaca TR, Longabaugh R. Mechanisms of change in motivational interviewing: a review and preliminary evaluation of the evidence. Addiction 2009; 104: 705-715.

[27] Urbán R. Motivational interviewing. In: Demetrovics Zs. (ed.) Basics of addictology III. The principles of treating addictions. [A motivációs interjú. In: Demetrovics Zs. (szerk.) Az addiktológia alapjai III. Az addikciók terápiájának alapkérdései.] ELTE Eötvös Kiadó, Budapest, 2009; pp. 277-293. [Hungarian]

(Pócs Dávid dr., Szeged, Hajnóczy u 13. 1/3, 6722 e-mail: drpocsdavid@gmail.com) 